\section{ДАФИНА ГРАДИНШЋАК}

ОШ „Владимир Назор”, Ђурђин

\section{НАТАША БРАНКОВИЋ ${ }^{2}$ ГОРДАНА КОЗОДЕРОВИЪ ${ }^{3}$}

Универзитет у Новом Саду

Педагошки факултет у Сомбору

\section{ПРЕГЛЕДНИ ЧЛАНАК}

UDK: $\quad 159.953 .5: 712.27$

BIBLID: 0353-7129, 26(2021)1, p.53-66

\title{
УЧЕЊЕ ЗАСНОВАНО НА БАШТОВАНСТВУ
}

\begin{abstract}
Резиме: Рад чини теоријски преглед истраживања, односно студија спроведених у оквиру учења заснованог на баштованству. У природи деца могу да усвајају разноврсна знања, вештине, као и да стекну или употпуне своју еколошку свесност и све то у амбијенту који представља свет живих примера. Човек се све више удаљава од природе иако она може много тога да му пружи и да буде подстицајно окружење за учење. Неопходно је вратити јој се и осмислити активности и програме у оквиру којих ће ученици усвајати знања у реалном свету непосредно. У раду је направљен осврт на студије везане за учење базирано на баштованству и то у оквиру пет домена: еколошки домен, домен школских постигнућа, домен исхраназдравље, психо-социјални домен и домен перцепција. Многи истраживачи креирали су и применили школске баштенске програме и пројекте, путем којих су остварени разноврсни позитивни утицаји на когнитивни, психо-социјални, морални и физички развој деце. Програми за учење засновани на баштованству резултирају повећањем свести о правилној исхрани и свести о животној средини, вишим постигнућима у учењу и повећањем животних вештина ученика. Искуства стечена у башти подстичу еколошку писменост и вештине управљања, побољшавају свест о вези између биљака и наше одеће, хране, начина живота и осећаја благостања.
\end{abstract}

Кључне речи: ученик, школско баштенско учење, баштенски програми, учење у природи

\section{Увод}

Када се говори о дефиницији учења заснованом на баштованству (gardenbased learning), може се рећи да не постоји њена јединствена дефиниција. Учење засновано на баштованству може бити дефинисано „као наставна стратегија која

1 dafina110@yahoo.com

2 natasa.brankovic@uns.ac.rs

3 gocakozoderovic@gmail.com 
користи башту као наставно средство“ (Desmond, Grieshop \& Subramaniam, 2004: 20). Међутим, аутори истичу да је приликом дефинисања оваквог учења важно узети у обзир и везе између баштенских искустава и образовне реформе, те баштенских искустава и трансформације савременог основног образовања у смислу преласка од седентарне реалности (неактивне, пасивне) до оне у којој постоји целокупна ангажованост детета. Такође, наводе да у дефиницију треба уградити и податак да баштенско искуство доприноси еколошкој писмености и одрживом развоју. (Desmond et al., 2004).

Како би се укратко приказао историјски развој идеје школског баштованства и уопште учења заснованог на баштованству, неопходно је навести значајне године, имена и догађаје кроз историју. Кратак историјски развој ове идеје дат је у табели.

Табела бр. 1. Школско баштованство - кратак историјски преглед најважнијх догађаја

\begin{tabular}{|c|c|c|}
\hline $\begin{array}{c}\text { Година/ } \\
\text { период }\end{array}$ & Догађај & Референца \\
\hline 1811. & $\begin{array}{l}\text { Пруска, обавезно школовање са баштенским активно- } \\
\text { стима }\end{array}$ & $\begin{array}{l}\text { Sealy, 2001, npe- } \\
\text { ma Subramaniam, } \\
2002 .\end{array}$ \\
\hline $\begin{array}{l}1814- \\
1880 .\end{array}$ & $\begin{array}{l}\text { Немачка, 1814; Аустрија и Шведска, } 1869 ; \text { Француска, } \\
\text { Русија и Белгија, } 1880 . \text { године - наставни планови школ- } \\
\text { ског баштованства и агрокултуре доступнији, а понекад } \\
\text { и обавезни }\end{array}$ & $\begin{array}{l}\text { Greene, 1910; } \\
\text { Lawson, } \\
\text { 2005, према } \\
\text { Nowatschin, } 2014 .\end{array}$ \\
\hline 1879. & $\begin{array}{l}\text { Erasmus Schwab, књига The School Garden о раној моти- } \\
\text { вацији за баштенско учење у Европи }\end{array}$ & $\begin{array}{l}\text { Meyer, } 1997, \\
\text { npema Desmond et } \\
\text { al., } 2004 .\end{array}$ \\
\hline 1891. & $\begin{array}{l}\text { Henry Lincoln Clapp, Масачусетс, прве школске баште у } \\
\text { Сједињеним Америчким Државама по узору на европске }\end{array}$ & $\begin{array}{l}\text { Sealy, 2001, npe- } \\
\text { ma Subramaniam, } \\
2002 .\end{array}$ \\
\hline $\begin{array}{l}1890- \\
1940 .\end{array}$ & $\begin{array}{l}\text { Омладинско баштованство прерасло у национални } \\
\text { покрет (до 1918. све државе у Америци и све провин- } \\
\text { ције у Канади имале су барем једну школску башту), } \\
\text { прогресивни реформатори су од школског баштованства } \\
\text { направили национални програм }\end{array}$ & $\begin{array}{l}\text { Sealy, 2001, npe- } \\
\text { Ma Subramaniam, } \\
\text { 2002; Trelstad, } \\
\text { 1997, npeмa } \\
\text { Nowatschin, } 2014 .\end{array}$ \\
\hline 1903. & $\begin{array}{l}\text { Аустралија - велики утицај на школски баштенски по- } \\
\text { крет имала годишња конференција о школским баштама } \\
\text { 1903.год }\end{array}$ & $\begin{array}{l}\text { Robin, 2001, npe- } \\
\text { Ma Subramaniam, } \\
2002 .\end{array}$ \\
\hline
\end{tabular}




\begin{tabular}{|c|c|c|}
\hline 1916. & $\begin{array}{l}\text { 1916. године, више од милион ученика је учествовало у } \\
\text { производњи хране, према прокламацији председника } \\
\text { Вудроа Вилсона (Woodrow Wilson) }\end{array}$ & $\begin{array}{l}\text { Sealy, 2001, npe- } \\
\text { ma Subramaniam, } \\
2002 .\end{array}$ \\
\hline $\begin{array}{l}\text { II свет- } \\
\text { ски рат }\end{array}$ & $\begin{array}{l}\text { Током II светског рата деца гајила тзв. victory баште } \\
\text { У Америци школске баште су изгубиле на својој обра- } \\
\text { зовној вредности након Првог светског рата, као и након } \\
\text { 1944. године }\end{array}$ & $\begin{array}{l}\text { Lawson, } \\
\text { 2005, према } \\
\text { Nowatschin, 2014; } \\
\text { Sealy, 2001, npe- } \\
\text { мa Subramaniam, } \\
2002 .\end{array}$ \\
\hline $\begin{array}{l}1900- \\
1930 . \\
1960- \\
1970 . \\
1990- \\
2000 .\end{array}$ & $\begin{array}{l}\text { Tри добра периода у САД-у за школски баштенски } \\
\text { покрет: } \\
\text { • } \\
\text { под утицајем прогресивног образовања и социјалне } \\
\text { реформе; } \\
\text { под утицајем покрета контракултуре и еколошког } \\
\text { покрета; } \\
\text { под утицајем поновног прогресивног образовања и } \\
\quad \text { поновног интересовања за еколошко образовање и } \\
\text { исхрану и здравље деце. }\end{array}$ & $\begin{array}{l}\text { Meyer, } 1997, \\
\text { npeмa Desmond et } \\
\text { al., } 2004 .\end{array}$ \\
\hline $\begin{array}{l}\text { од } 1993 . \\
\text { па на- } \\
\text { даље }\end{array}$ & $\begin{array}{l}\text { Америчко хортикултурално удружење } 1993 . \text { године фор- } \\
\text { мирало први симпозијум за омладинско баштованство }\end{array}$ & $\begin{array}{l}\text { Sealy, 2001, npe- } \\
\text { ma Subramaniam, } \\
2002 .\end{array}$ \\
\hline
\end{tabular}

У контексту образовања баштованство постоји као дуга традиција. Кроз историју се могу приметити поједини значајни теоретичари и филозофи образовања који су придавали значај баштованству као образовном средству (Marturano, 1999, према Nowatschin, 2014). Тако може да се говори о Коменском, који је сматрао да би школске баште требале да буду део сваке школе у оквиру којих би ученици могли да уживају у дрвећу, цвећу, биљкама и очекују да чују и виде нешто ново. Истичући чула као важне чиниоце који утичу на памћење, Коменски је сматрао да ће баште, које је назвао методом чулне перцепције, узроковати трајно задржавање знања (Comenius, 1967, према Desmond et al., 2004). Жан Жак Русо сматрао је да је природа важан део образовања, као и да је она највећи дететов учитељ (Sealy, 2001, према Subramaniam, 2002). Значајно је споменути и Песталоција, који је познат по својој школи у којој је практично образовање спровођено кроз баштованство, пољопривреду и домаћинске вештине (Froebel Web site, 1998, према Subramaniam, 2002), као и Фридриха Фребела, познатог по свом програму предшколског образовања, односно по школама које су поседовале баште за учење (Herrington, 1998, према Nowatschin, 2014). Марија Монтесори је сматрала да баште могу да утичу на морални развој деце и на њихово уважавање природе, поштовање према њој (Montessori, 1912, према Subramaniam, 2002). Последњи, али не мање важан, Џон Дјуи, сматра да школе са баштама деци могу 
да пруже средину у којој би могле да се произведу животне ситуације, као и да се стичу и примењују информације и идеје (Dewey, 1944, према Subramaniam, 2002).

С обзиром на то да су познати филозофи и педагози истицали природу и природна окружења као важна едукативна окружења, јасно је да сви они који користе башту као средину за учење, у ствари следе мишљења ових светски познатих мислилаца.

Постоји велики број истраживања о учењу заснованом на баштованству, која су се бавила испитивањем различитих аспеката. Резултати датих истраживања везани за школско баштованство, могли би да се сврстају у неколико група - категорија: еколошки домен, домен исхрана - здравље, домен школских постигнућа, психо-социјални домен и домен перцепција.

\section{ЕкОЛОШКИ ДОМЕН}

Један од важних задатака нашег образовног система, а посебно наставе природних наука јесте да од деце створе еколошке зналце, односно еколошки одговорна и свесна бића. Наставни кадар треба да омогући услове и стратегије које подразумевају учење у непосредној околини, учење у реалном свету, у природним лабораторијама (у природи), јер је познато да овакво учење даје позитивне резултате. Многи истраживачи посветили су пажњу еколошком образовању, еколошким ставовима и еколошкој свести у контексту учења заснованог на баштованству, па су тако испитивали утицај баштенских програма на поменуте аспекте или сумирали резултате из ове области у свом научном раду.

Бројна истраживања показала су да баштенски програми позитивно утичу на еколошке ставове ученика, односно еколошку свест (Fisher-Maltese, 2016; Fisher-Maltese \& Zimmerman, 2015; Conlon Morgan, Hamilton, Bentley \& Myrie, 2009; Plaka \& Skanavis, 2016; Skelly \& Zajicek, 1998; Waliczek \& Zajicek, 1999).

Скели и Кембел Бредли (2007) у свом раду сумирају студије „о школским баштенским програмима и њиховим варијацијама и утицају оваквих варијација на осећај одговорности и ставове према природним наукама и животној средини код 427 ученика трећег разреда" (Skelly \& Campbell Bradley, 2007: 97). Ауторке су од варијација школских баштенских програма направиле типологију која је подразумевала „интензитет (број баштенских активности у којима су ученици учествовали пре и за време боравка у башти)“ и „облик (цвеће, поврће, комбинација)" (Skelly \& Campbell Bradley, 2007: 100), те је из дате систематизације формирано девет типова башта. Код резултата везаних за ученичку одговорност и еколошке ставове нису пронађене значајне разлике, али су резултати у оквиру ова два аспекта били веома високи, из чега произилази осећај одговорности и позитивни еколошки ставови. Када је реч о еколошким ставовима, истакнуто је да су најбољи резултати остварени у комбинованим баштама ниског интензитета 
и цветним баштама средњег и ниског интензитета, док се најлошији резултати спомињу у контексту поврћних башта високог и средњег интензитета.

Истражен је утицај искустава са природом (биљкама из детињства) на еколошке ставове, понашања и активности везане за природу и баштованство у каснијем животу испитаника, када деца одрасту (Broom, 2017; Lohr и Pearson-Mims, 2005). Изведен је закључак да постоје „везе између позитивних искустава у природи из детињства и негујућег става према околини у одраслом добу" (Broom, 2017: 38). Акцентовано је да су постојале корелације када је реч о поседовању позитивних искустава путем игре у природи током детињства и идентификације самих себе као особа које воле природу у одраслом добу (корелација 87\%); затим када је реч о неигрању у природи и поседовању неутралног погледа на природу (корелација 100\%), као и када се говори о љубави према природи и сматрању природе приоритетом (корелација 84\%). Међутим, ауторка је уочила да сматрање животне средине приоритетом, није нужно значило да су ти појединци били брижнији у контексту животне средине од оних који је нису сматрали приоритетом. У сродном истраживању уочене су везе између одрастања поред зелених површина, обилажења паркова, присуствовања еколошким часовима, баштенских активности током детињства и позитивнијих ставова везаних за дрвеће, као и више активности код испитаника у одраслом добу (Lohr \& Pearson-Mims, 2005). Резултати су такође показали да одрастање у урбаним срединама, односно поред великих зграда, утиче - али да је тај утицај мали и супротан. Ауторке су истакле да су постојале везе између пасивних и активних интеракција са биљкама током детињства и позитивних вредновања код одраслих, везаних за дрвеће, али ипак у контексту најјачег утицаја спомињу активно баштованство, односно брање цвећа или сађење дрвећа.

\section{ДОМЕН ИСХРАНА - ЗДРАВЉЕ}

Постоји много студија које се баве истраживањем здраве хране, као и истраживањем утицаја хране на људско тело, те стога постоји много различитих становишта и праваца у овом домену. Чињеница јесте да човек храном утиче на стање свог тела и ума, односно на своје физичко и ментално стање. Дакле, у зависности од тога шта конзумирају и у којој мери, људи могу да уживају у здравом животу или да се боре са широким спектром лакших и тежих болести. Наравно да храна није једини фактор који утиче на људско здравље, али јесте један од важних фактора. С обзиром на то да постоји мноштво различитих информација и праваца у погледу здраве исхране, човек заиста треба да се потруди и посвети истраживању овог, за њега веома важног животног поља. Човек се све више удаљава од природе, па се тако удаљава од ње и када је реч о исхрани. Исхрану све више чине индустријски прерађени производи и брза храна, а све мање природна храна попут воћа, поврћа, семенки и орашастих плодова. Можда не треба отићи у крајност, па следити мишљење да сваки производ који на себи 
има бар-код не треба конзумирати, али свакако је потребно следити здрав разум и уносити што више природне хране. Веома је важно створити навике везане за здраву исхрану већ код мале деце, јер су оне основа за њихов даљи здрав живот. С обзиром на претходно наведене чињенице, један од важних задатака наставног кадра јесте да ученицима омогући услове у којима ће они усвајати квалитетна, практична знања о овој тако важној области.

Може се рећи да постоји велики број истраживања о утицају школских баштенских програма на разне аспекте везане за здраву исхрану и здравље. Тако су истраживачи остварили позитивне резултате у оквиру испитивања утицаја баштенских програма/школских башта на аспекте дате у табели.

Табела бр. 2. Преглед најважнијих истраживања учења заснованог на баштованству (утичај на здраву исхрану и здравље)

\begin{tabular}{|c|c|c|}
\hline $\begin{array}{l}\text { Утицај баштен- } \\
\text { ских програма/ } \\
\text { школских } \\
\text { башта: }\end{array}$ & $\begin{array}{c}\text { Најзначајнији налази } \\
\text { истраживања }\end{array}$ & $\begin{array}{c}\text { Истраживачи који су се бавили } \\
\text { овом проблематиком }\end{array}$ \\
\hline $\begin{array}{l}\text { • на знање о } \\
\text { исхрани; }\end{array}$ & $\begin{array}{l}\text { • побољшање знања о воћу и } \\
\text { поврћу; } \\
\text { • повећање способности да се } \\
\text { идентификује поврће; }\end{array}$ & $\begin{array}{l}\text { Koch, Waliczek \& Zajicek, 2006; } \\
\text { Morgan et al., 2010; Morris, Briggs } \\
\text { и Zidenberg-Cherr, 2002; Parmer, } \\
\text { Salisbury-Glennon, Shannon \& } \\
\text { Struempler, 2009. } \\
\end{array}$ \\
\hline $\begin{array}{l}\text { - на понашање } \\
\text { везано за ис- } \\
\text { храну; } \\
\end{array}$ & $\begin{array}{l}\text { • побољшање понашања везаног } \\
\text { за тражење воћа и поврћа код } \\
\text { куће; }\end{array}$ & $\begin{array}{l}\text { Heim, Stang \& Ireland, 2009; } \\
\text { Morris et al., } 2002 .\end{array}$ \\
\hline $\begin{array}{l}\text { • на преферен- } \\
\text { ције према } \\
\text { воћу и/или } \\
\text { поврћу; }\end{array}$ & $\begin{array}{l}\text { • побољшане преференције према } \\
\text { поврћу; } \\
\text { • у подгрупи гојазних и са пре- } \\
\text { комерном тежином присутно } \\
\text { побољшање у преференцијама } \\
\text { према поврћу; }\end{array}$ & $\begin{array}{l}\text { Gatto, Ventura, Cook, } \\
\text { Gyllenhammer, Davis, 2012; Heim } \\
\text { et al., 2009; Morgan et al., 2010; } \\
\text { Morris et al., 2002; Parmer et al., } \\
\text { 2009; Triador, Farmer, Maximova, } \\
\text { Willows и Kootenay, } 2015 . \\
\end{array}$ \\
\hline $\begin{array}{l}\text { • на конзумацију } \\
\text { (унос) воћа и/ } \\
\text { или поврћа; }\end{array}$ & $\begin{array}{l}\text { • већа спремност да се изабере } \\
\text { поврће у оквиру школског } \\
\text { ручка; } \\
\text { • ученици су јели значајно више } \\
\text { поврћа према пост-тесту; }\end{array}$ & $\begin{array}{l}\text { Heim et al., 2009; Hermann et al., } \\
\text { 2006; Koch et al., 2006; Morris et } \\
\text { al., 2002; Parmer et al., } 2009 .\end{array}$ \\
\hline $\begin{array}{l}\text { • на ставове } \\
\text { према воћу и/ } \\
\text { или поврћу; }\end{array}$ & $\begin{array}{l}\text { • ставови ученика према поврћу } \\
\text { значајно су позитивнији (мере- } \\
\text { не су преференције); } \\
\text { • ставови према воћу и поврћу } \\
\text { као ужини значајно су позитив- } \\
\text { нији (мерене су преференције); }\end{array}$ & $\begin{array}{l}\text { Lineberger \& Zajicek, 2000; Morris } \\
\text { et al., } 2002 .\end{array}$ \\
\hline $\begin{array}{l}\text { • на физичку } \\
\text { активност. }\end{array}$ & $\begin{array}{c}\text { - значајно више деце је пријавило } \\
\text { да су физички активна сваки дан. }\end{array}$ & $\begin{array}{l}\text { Hermann et al., 2006; Wells, Myers } \\
\text { \& Henderson Jr., 2014. }\end{array}$ \\
\hline
\end{tabular}




\section{ДОМЕН ШКОЛСКИХ ПОСТИГНУЋА (ШКОЛСКИ УСПЕХ)}

Истраживачи су посветили пажњу и утицају школских баштенских програма на школска постигнућа. Иако је познато да школски баштенски програми могу да имају позитиван утицај на постигнућа у оквирима разних наставних предмета (математика, језик, уметност, историја), овде смо посматрали утицај баштенских програма на постигнућа у оквиру природних наука.

У истраживањима која су реализована током 2005. године испитан је утицај баштенског курикулума Junior Master Gardener Handbook Level One на постигнућа ученика из природних наука. У оквиру експерименталне групе постојала је значајна разлика када се упореде резултати пре и после тестова везаних за постигнућа из природних наука, док у оквиру контролне групе то није био случај. Иако није пронађена значајна разлика између ове две групе услед третмана, аутори истичу да добијени резултати указују на то „да се применом баштенских активности једном недељно и практичних учионичких активности” може позитивно утицати на постигнућа из природних наука (Smith и Motsenbocker, 2005: 439).

Током исте године (2005) проучавана су постигнућа из природних наука код ученика трећих, четвртих и петих разреда, и то упоређујући контролну (са традиционалним учионичким методама) и експерименталну групу (са традиционалним учионичким методама и школским баштенским активностима). Резултати су показали да су ученици експерименталне групе остварили статистички значајно боље резултате у оквиру постигнућа из природних наука у односу на контролну групу ученика. Експериментални програм био је једнако ефикасан при учењу природних наука и за дечаке и за девојчице из експерименталне групе, будући да аутори нису пронашли статистички значајну разлику у односу на пол (Klemmer, Waliczek \& Zajicek, 2005).

Један од два главна циља истраживања које је спроведено током 2016. године (Ray, Fisher \& Fisher-Maltese, 2016) био је да се утврди да ли ученици који у школама имају школску башту постижу боље академске (школске) резултате, односно школска постигнућа, у односу на оне који у оквиру својих школа немају баште. Резултати су показали да су ученици из школа са баштама постигли боље резултате из математике, читања и природних наука. Уколико се базирамо само на резултате из природних наука, аутори истичу да између школа са баштама и резултата тестова из природних наука постоји значајна и позитивна повезаност.

Група истраживача бавила се сличном тематиком током 2015. године, фокус њихове студије био је на ефектима школског баштенског третмана у оквиру знања из природних наука ученика основних школа (Wells et al. 2015). Баштенски третман (интервенција) подразумевао је баштенске гарнитуре са баштенским активностима (садња, уклањање корова и берба), као и лекције везане за исхрану, хортикултуру и науку о биљкама. Истраживање је указало на веће побољшање знања из природних наука код ученика који су били подвргнути баштенском 
третману, у поређењу са контролном групом, иако су резултати везани за ова знања били лоши. Важно је напоменути да су аутори дошли и до закључка да што су јаче, снажније баштенске интервенције примењене, јачи су и резултати, односно знања из природних наука.

\section{ПСИХО-СОЦИЈАЛНИ ДОМЕН}

Психо-социјалне вештине такође су биле предмет многих истраживања у контексту учења заснованом на баштованству. У оквиру психо-социјалног аспекта учења заснованом на баштованству може се споменути рад аутора који су у свом истраживању дошли до закључка ,да је башта подстакла социјалне интеракције” међу децом, те да је башта амбијент, односно „окружење наклоњено детету" (Laaksoharju et al., 2012:195).

Занимљиво је истраживање које је имало за циљ да испита утицај баштенских активности на међуљудске односе и ставове према школи (Waliczek, Bradle $\&$ Zajicek, 2001). Када су упоређени пре и пост-тестови (иницијални и финални тестови), као и контролна и експериментална група, утврђено је да нису постојале значајне разлике међу њима, али је демографском анализом утврђено „да су девојчице имале значајно позитивније ставове према школи на крају баштенског програма у поређењу са дечацима" (Waliczek et al., 2001: 467). Код ученика седмих разреда запажени су најпозитивнији резултати интерперсоналних односа, а разлог томе, како аутори наводе, може бити тај што су старија деца имала дозволу за независан рад, што може довести до повећања социјализације, док су млађа деца током рада била више надгледана. Аутори су такође запазили да су код ученика из школа у оквиру којих су они имали могућност за више индивидуалног рада, ставови према школи били позитивнији у односу на ученике других школа обухваћених студијом.

Група истраживача испитивала је утицај куварског и баштенског програма аустралијских основних школа „на ширу социјалну средину и средину за учење у школи" (Block et al., 2012: 421). Примарна анализа односила се на квалитативне податке добијене од ученика, родитеља, наставника, волонтера, директора и стручног особља преко интервјуа, фокус група и запажања испитаника. Аутори су то поткрепили анализама квантитативних података о квалитету живота детета, кооперативном понашању, перцепцији наставника о школском окружењу, образовним исходима на школском нивоу и изостанцима. Даље истичу да су особине програма које су учесници сматрали највреднијима биле: „повећана ученичка ангажованост и самопоуздање, могућности за искуствено и интегрисано учење, тимски рад, изградња социјалних вештина, и везе и односи између школа и њихових заједница" (Block et al., 2012: 419). На крају аутори напомињу да у овој анализи, налази из примарне анализе нису подржани од стране квантитативних налаза. 
Испитани су утицаји двогодишњег баштенског програма на образовне исходе и понашање појединца код проблематичних средњошколских ученика и ученика са лошим успехом (Ruiz-Gallardo, Verde \& Valdés, 2013). Аутори истичу позитивне резултате ових ученика (статистички значајно побољшање у понашању и вештинама, самопоштовању и самопоуздању; формирање бољих ставова према школи; развијање одговорности према баштенским активностима) - што све води ка бољој атмосфери у учионици. Значајни подаци тичу се и стопе напуштања, која је смањена, као и броја положених предмета, који је био статистички значајно већи у односу на претходну годину.

\section{ДОМЕН ПЕРЦЕПЦИЈА}

Када је реч о истраживањима заснованим на перцепцијама везаним за школске баштенске програме, постоји одређен број истраживача који су дали свој допринос на овом пољу (Hilgers, Haynes \& Olson, 2008; Bowker \& Tearle, 2007; Graham, Beall, Lussier, Mclaughlin \& Zidenberg-Cherr, 2005; Murakami, Pharr \& Bungum, 2016; Akoumianaki-Ioannidou, Paraskevopoulou \&Tachou, 2016).

Запажена су истраживања перцепције родитеља везане за интересовања и свесност њихове деце након примењеног Growing in the Garden програма (Hilgers et al., 2008). Резултати су указали на то да је већина родитеља уочила да су свесност и интересовања њихове деце у оквиру природе и животне средине биле повећане.

Студија групе истраживача фокусирана је на утврђивање статуса, односно положаја башта у школама Калифорније (Graham et al., 2005). Из резултата се уочава да је „најчешћи разлог за поседовање баште био побољшање наставних инструкција" (Graham et al., 2005: 149) и углавном су оне биле коришћене за процес учења природних наука, еколошких области и за учење о исхрани. Директори (испитаници) сматрају да би за примену школских башта у контексту наставних сугестија помогли наставни планови (курикулуми) повезани са наставним инструкцијама и лекцијама у башти (везаним за исхрану).

Запажена је студија о утицају раних фаза међународног пројекта Gardens for Life на дечије перцепције о школском баштованству и њихово учење (Bowker $\&$ Tearle, 2007). Из студије се уочава позитиван утицај на учење и на дечије перцепције према школском баштованству.

У контексту испитивања перцепција везаних за школске баштенске програме, могу се споменути две студије настале током 2016. године (Murakami et al., 2016; Akoumianaki-Ioannidou et al., 2016).

Првом студијом група истраживача желела је да прикаже каква је тренутна пракса директора и наставника, да утврде перцепције о предностима и баријерама школских башта, као и да дају свој допринос по питању ресурса потребних за успешно функционисање школских башта (Murakami et al., 2016). Када се говори о потребним ресурсима, већина наставника истиче наставничку обуку као 
важан ресурс (61\%), али такође сматрају важним и финансирање и приступ баштенском курикулуму, док највећи број директора (71\%) сматра да је то пре свега - финансирање. Наставници као баријере у баштенском раду наводе недостатак времена, искуства и обуке. Када је реч о добробити школских башта, велики број наставника сматра да су то повећање знања о исхрани, забава за наставнике и ученике, одлично средство за учење. Директори као главне вредности истичу побољшање социјалних вештина и повећање ангажованости заједнице. Као неки од закључака студије наводе се: наставницима је потребан додатни професионални развој и подршка директора ради побољшања њиховог знања везаног за башту; проводећи време унутар баште, директори би боље разумели учење у оваквој средини и предности оваквог учења; за успешну школску башту важни су подршка директора и заинтересованост наставника за башту.

Друга истраживачка студија базирана је на испитивању ученика и наставника средњих школа из Грчке, а фокус им је био на перцепцијама везаним за тренутно сађење у школском дворишту и за преференције према биљном материјалу, као и на перцепцијама везаним за активности и употребу школског дворишта за сађење у контексту омогућавања контакта ученик - биљка. Наставници и ученици су врло мало тога знали о биљкама из школског дворишта, а сам биљни материјал је био веома мало коришћен на школским часовима и активностима. Даљи резултати су показали да би и ученици и наставници волели да се биљни материјал укључи у активности и школске часове, те су аутори дошли и до закључка да је неопходна обука наставника . Неки генерални закључак до ког су аутори дошли јесте да се из студије може уочити потенцијал школског сађења у контексту повећања контакта ученика са биљакама и побољшања њиховог знања о биљкама и околини уопште (Akoumianaki-Ioannidou et al. 2016).

\section{ЗАКљУЧАК}

С обзиром на велики број истраживања која су се бавила учењем базираним на баштованству, и на њихове позитивне резултате - потпуно је јасно зашто је оваква стратегија за учење нашла своју примену у многим школама широм света. Истраживачи су били оријентисани на различите аспекте школског баштованства, односно на еколошко образовање, исхрану и здравље, различите психо-социјалне вештине, школска - академска постигнућа, различите перцепције везане за баштенске програме. Многи од њих су осмислили и применили веома квалитетне школске баштенске програме и пројекте, којима су позитивно утицали на когнитивни, психо-социјални, морални и физички развој деце. Оваквим програмима се код деце повећава свест о здравој исхрани и животној средини, подстиче еколошка писменост као и њихова повезаност са животном средином и биљкама. Искуства у оквиру ових програма доносе и виша постигнућа у учењу, развој социјалних интеракција и социјалних вештина, самопоуздања, самопоштовања и животних вештина ученика. Башта представља лабораторију на отво- 
реном у којој дете може да преузме улогу младог научника, који знања и вештине стиче у реалном свету обогаћеном различитим занимљивим активностима.

И поред велике пажње истраживача широм света усмерене на ову тему, већина школа у Србији не користи школска дворишта и баште као средине у којима би деца усвајала знања и вештине. Најпре је неопходно упознати наставни кадар са многобројним предностима школских баштенских програма, односно са чињеницом да такви програми представљају моћну стратегију путем које се на иновативан начин постижу образовно-васпитни циљеви.

\section{ЛИТЕРАТУРА}

Akoumianaki-Ioannidou, A., Paraskevopoulou, A. T., \& Tachou, V. (2016). School grounds as a resource of green space to increase child-plant contact. Urban Forestry \& Urban Greening, 20(1), 375-386. doi: 10.1016/j.ufug.2016.10.009.

Block, K., Gibbs, L., Staiger, P. K., Gold, L., Johnson, B., Macfarlane, S., Long, C., \& Townsend, M. (2012). Growing Community: The Impact of the Stephanie Alexander Kitchen Garden Program on the Social and Learning Environment in Primary Schools. Health Education \& Behavior, 39(4), 419-432. doi: $10.1177 / 1090198111422937$.

Bowker, R., \& Tearle, P. (2007). Gardening as a Learning Environment: A Study of Children's Perceptions and Understanding of School Gardens as Part of an International Project. Learning Environments Research, 10(2), 83-100. doi: 10.1007/ s10984-007-9025-0.

Broom, C. (2017). Exploring the Relations Between Childhood Experiences in Nature and Young Adults' Environmental Attitudes and Behaviours. Australian Journal of Environmental Education, 33(1), 34-47. doi: 10.1017/aee.2017.1.

Conlon Morgan, S., Hamilton, S. L., Bentley, M. L., \& Myrie, S. (2009). Environmental Education in Botanic Gardens: Exploring Brooklyn Botanic Garden's Project Green Reach. The Journal of Environmental Education, 40(4), 35-52. doi: 10.3200/JOEE.40.4.35-52.

Desmond, D., Grieshop, J., \& Subramaniam, A. (2004). Revisiting Garden Based Learning in Basic Education Philosophical Roots, Historical Foundations, Best Practices and Products, Impacts, Outcomes, and Future Directions. Rome, Paris: Food and Agriculture Organization of the United Nations, International Institute for Educational Planning.

Fisher-Maltese, C. (2016). "We won't hurt you butterfly!" Second-graders become environmental stewards from experiences in a school garden. International Journal of Early Childhood Environmental Education, 4(1), 54-69.

Fisher-Maltese, C., \& Zimmerman, T. D. (2015). A Garden-Based Approach to Teaching Life Science Produces Shifts in Students' Attitudes toward the Environment. International Journal of Environmental \& Science Education, 10(1), 51-66. doi: 10.12973/ijese.2015.230a. 
Gatto, N. M., Ventura, E. E., Cook, L. T., Gyllenhammer, L. E., \& Davis, J. N. (2012). LA Sprouts: A Garden-Based Nutrition Intervention Pilot Program Influences Motivation and Preferences for Fruits and Vegetables in Latino Youth. Journal of the Academy of Nutrition and Dietetics, 112(6), 913-920. doi: 10.1016/j. jand.2012.01.014.

Graham, H., Beall, D. L., Lussier, M., Mclaughlin, P., \& Zidenberg-Cherr, S. (2005). Use of School Gardens in Academic Instruction. Journal of Nutrition Education and Behavior, 37(3), 147-151. doi: 10.1016/S1499-4046(06)60269-8.

Heim, S., Stang, J., \& Ireland, M. (2009). A Garden Pilot Project Enhances Fruit and Vegetable Consumption among Children. Journal of the American Dietetic Association, 109(7), 1220-1226. doi: 10.1016/j.jada.2009.04.009.

Hermann, J. R., Parker, S. P., Brown, B. J., Siewe, Y. J., Denney, B. A., \& Walker, S. J. (2006). After-School Gardening Improves Children's Reported Vegetable Intake and Physical Activity. Journal of Nutrition Education and Behavior, 38(3), 201-202. doi: 10.1016/j.jneb.2006.02.002.

Hilgers, K. R., Haynes, C., \& Olson, J. (2008). Assessing a Garden-based Curriculum for Elementary Youth in Iowa: Parental Perceptions of Change. HortTechnology, 18(1), 18-23. doi: 10.21273/HORTTECH.18.1.18.

Klemmer, C. D., Waliczek, T. M., \& Zajicek, J. M. (2005). Growing Minds: The Effect of a School Gardening Program on the Science Achievement of Elementary Students. HortTechnology, 15(3), 448-452. doi: 10.21273/HORTTECH.15.3.0448.

Koch, S., Waliczek, T. M., \& Zajicek, J. M. (2006). The Effect of a Summer Garden Program on the Nutritional Knowledge, Attitudes, and Behaviors of Children. HortTechnology, 16(4), 620-625. doi: 10.21273/HORTTECH.16.4.0620.

Laaksoharju, T., Rappe, E., \& Kaivola, T. (2012). Garden affordances for social learning, play, and for building nature-child relationship. Urban Forestry \& Urban Greening, 11(2), 195-203. doi: 10.1016/j.ufug.2012.01.003.

Lineberger, S. E., \& Zajicek, J. M. (2000). School Gardens: Can a Hands-on Teaching Tool Affect Students' Attitudes and Behaviors Regarding Fruit and Vegetables? HortTechnology, 10(3), 593-597. doi: 10.21273/HORTTECH.10.3.593.

Lohr, V. I., \& Pearson-Mims, C. H. (2005). Children's Active and Passive Interactions with Plants Influence Their Attitudes and Actions toward Trees and Gardening as Adults. HortTechnology, 15(3), 472-476. doi: 10.21273/HORTTECH.15.3.0472.

Morgan, P. J., Warren, J. M., Lubans, D. R., Saunders, K. L., Quick, G. I., \& Collins, C. E. (2010). The impact of nutrition education with and without a school garden on knowledge, vegetable intake and preferences and quality of school life among primary-school students. Public Health Nutrition, 13(11), 1931-1940. doi: 10.1017/S1368980010000959.

Morris, J. L., Briggs, M., \& Zidenberg-Cherr, S. (2002). Development and Evaluation of a Garden-Enhanced Nutrition Education Curriculum for Elementary Schoolchildren. The Journal of Child Nutrition \& Management, 26(1), 1-12. 
Murakami, T., Pharr, J., \& Bungum, T. (2016). Educators' Perceptions Associated with School Garden Programs in Clark County, Nevada: Practices, Resources, Benefits and Barriers. Journal of Nutrition \& Food Sciences, 6(2), 1-7. doi: 10.4172/2155-9600.1000465.

Nowatschin, E. A. (2014). Educational Food Landscapes Developing Design Guidelines for School Gardens. [Neobjavljena master teza]. The University of Guelph.

Parmer, S. M., Salisbury-Glennon, J., Shannon, D., \& Struempler, B. (2009). School Gardens: An Experiential Learning Approach for a Nutrition Education Program to Increase Fruit and Vegetable Knowledge, Preference, and Consumption among Second-grade Students. Journal of Nutrition Education and Behavior, 41(3), 212 217. doi: 10.1016/j.jneb.2008.06.002.

Plaka, V., \& Skanavis, C. (2016). The feasibility of school gardens as an educational approach in Greece: a survey of Greek schools. International Journal of Innovation and Sustainable Development, 10(2), 141-159. doi: 10.1504/IJISD.2016.075546.

Ray, R., Fisher, D. R., \& Fisher-Maltese, C. (2016). SCHOOL GARDENS IN THE CITY: Does Environmental Equity Help Close the Achievement Gap?. Du Bois Review: Social Science Research on Race, 13(2), 379-395. doi: 10.1017/ S1742058X16000229.

Ruiz-Gallardo, J-R., Verde, A., \& Valdés, A. (2013). Garden-Based Learning: An Experience With “At Risk" Secondary Education Students. The Journal of Environmental Education, 44(4), 252-270. doi: 10.1080/00958964.2013.786669.

Skelly, S. M., \& Campbell Bradley, J. (2007). The Growing Phenomenon of School Gardens: Measuring Their Variation and Their Affect on Students' Sense of Responsibility and Attitudes Toward Science and the Environment. Applied Environmental Education and Communication, 6(1), 97-104. doi: 10.1080/15330150701319438.

Skelly, S. M., \& Zajicek, J. M. (1998). The Effect of an Interdisciplinary Garden Program on the Environmental Attitudes of Elementary School Students. HortTechnology, 8(4), 579-583. doi: 10.21273/HORTTECH.8.4.579.

Smith, L. L., \& Motsenbocker, C. E. (2005). Impact of Hands-on Science through School Gardening in Louisiana Public Elementary Schools. HortTechnology, 15(3), 439-443. doi: 10.21273/HORTTECH.15.3.0439.

Subramaniam A. (2002). Garden-Based Learning in Basic Education: A Historical Review. 4-H Center for Youth Development, University of California, Davis.

Triador, L., Farmer, A., Maximova, K., Willows, N., \& Kootenay, J. (2015). A School Gardening and Healthy Snack Program Increased Aboriginal First Nations Children's Preferences Toward Vegetables and Fruit. Journal of Nutrition Education and Behavior, 47(2), 176-180. doi: 10.1016/j.jneb.2014.09.002.

Waliczek, T. M., Bradley, J. C., \& Zajicek, J. M. (2001). The Effect of School Gardens on Children's Interpersonal Relationships and Attitudes Toward School. HortTechnology, 11(3), 466-468. doi: 10.21273/HORTTECH.11.3.466. 
Waliczek, T. M., \& Zajicek, J. M. (1999). School Gardening: Improving Environmental Attitudes of Children Through Hands-On Learning. Journal of Environmental Horticulture, 17(4), 180-184. doi: 10.24266/0738-2898-17.4.180.

Wells, N. M., Myers B. M., \& Henderson Jr. C. R. (2014). School gardens and physical activity: A randomized controlled trial of low-income elementary schools. Preventive medicine, 69, Supplement, S27-S33. doi: 10.1016/j.ypmed.2014.10.012.

Wells, N. M., Myers, B. M., Todd, L. E., Barale, K., Gaolach, B., Ferenz, G., Aitken, M., Henderson Jr. C. R., Tse, C., Ostlie Pattison, K., Taylor, C., Connerly, L., Carson, J. B., Gensemer, A. Z., Franz, N. K., \& Falk, E. (2015). The Effects of School Gardens on Children's Science Knowledge: A randomized controlled trial of low-income elementary schools. International Journal of Science Education, 37(17), 2858-2878. doi: 10.1080/09500693.2015.1112048.

\section{Gardening-based learning}

Summary: The paper provides a theoretical overview of studies conducted within the framework of gardening-based learning. In nature, children can acquire a variety of skills and develop their environmental awareness in a space that represents a world of living examples. People are distancing from the nature, despite the fact that it can be a stimulating learning environment. It is necessary to return to the nature and design activities and programs where students will directly learn in the real world. The paper reviews the studies related to gardening-based learning within five domains: ecological, psychosocial, perceptual, the domain of school achievement and nutrition-health. Many researchers have created and implemented school garden programs and projects through which various positive effects have been achieved on cognitive, psychosocial, moral and physical development of children. Gardening-based learning programs result in increased awareness of proper nutrition and environment, higher learning outcomes and increase students' life skills. Experience gained in the garden encourage environmental literacy and management skills, improve awareness of the connection between plants and our clothes, food, lifestyle and sense of well-being. Keywords: student, school gardening learning, garden programs, learning in nature 